\title{
In vitro Mass Clonal Propagation of Spathoglottis plicata Blume
}

\author{
Pinaki Sinha, M. Lokman Hakim ${ }^{1}$ and M. Firoz Alam* \\ Department of Botany, Rajshahi University, Rajshahi, Bangladesh \\ Key words: Spathoglottis plicata, Clonal propagation, Acclimation
}

\begin{abstract}
For in vitro clonal propagation of Spathoglottis plicata Blume nodal segments of young shoots were cultured on half strength of MS with $2 \%$ sucrose $+2.0 \mathrm{mg} / \mathrm{l}$ $\mathrm{BA}+0.5 \mathrm{mg} / \mathrm{l} \mathrm{NAA}+2 \mathrm{~g} / \mathrm{l}$ peptone $+15 \%(\mathrm{v} / \mathrm{v}) \mathrm{CW}+0.5 \mathrm{~g} / \mathrm{l} \mathrm{AC}$, incubated at 24 $\pm 2^{\circ} \mathrm{C}$ under 3000 lux fluorescent light for a $16 \mathrm{hr}$ photoperiod per day. About 19 micro-shoots were induced from the explants within 12 weeks. Subculture of micro-shoots for eight weeks on the same nutrient medium enhanced the number of micro-shoots up to 60 . The clumps of the micro-shoots were dissected and cultured on half strength of MS with $2 \%$ sucrose $+2 \mathrm{~g} / 1$ peptone $+15 \%(\mathrm{v} / \mathrm{v})$ $\mathrm{CW}+0.5 \mathrm{~g} / \mathrm{l} \mathrm{AC}+200 \mathrm{mg} / \mathrm{l} \mathrm{L-glutamine}$. The micro-shoot sections elongated to form shoots, and new micro shoots were induced from the base within eight weeks of culture. For plantlet formation the best rooting medium was determined as half strength of MS with $2 \%$ sucrose $+2 \mathrm{~g} / \mathrm{l}$ peptone $+15 \%(\mathrm{v} / \mathrm{v})$ $\mathrm{CW}+0.5 \mathrm{~g} / \mathrm{l} \mathrm{AC}+50 \mathrm{~g} / \mathrm{l}$ banana pulp. After rearing $25 \mathrm{~g}$ mixture of urea, TSP and MOP $(2: 1: 1)$ were applied per plant at three months intervals. All the regenerated plants blossomed on the third year.
\end{abstract}

\section{Introduction}

Spathoglottis plicata Blume is a handsome terrestrial orchid species, with long, grassy leaves, and about $7.5 \mathrm{~cm}$ wide flowers on erect spikes, which are quite attractive having long blooming period. Its inflorescence is erect, about $75 \mathrm{~cm}$ long, densely 5 - 25 flowered, often with pinkish bracts. At maturity plants flowered almost throughout the year. It is distributed in Bangladesh, India and Indonesia (Mukherjee 2002). In Bangladesh the plant is naturally grown in Chittagong (Huda et al. 1999) but in the garden it is used as ornamental pot plant.

*Author for correspondence: <falambt@yahoo.com>. ${ }^{1}$ Institute of Food and Radiation Biology, Bangladesh Atomic Energy Commission, Gonokbari, Savar, Dhaka, Bangladesh. 
Spathoglottis plicata is conventionally propagated through separation of pseudobulbs but the proliferation rate is very low. A more efficient approach for its regeneration is in vitro seed culture (Sarker and Roy 1993, Roy and Biswas 2004). For mass clonal propagation, regeneration from nodal segments and axillary bud explants is superior to seed culture due to availability of plant materials round the year, an exponential propagation rate and sustaining the parental characteristics in regenerated plants. Reports on the in vitro culture of Spathoglottis plicata are limited (Lim-Ho et al. 1984, Teng et al. 1997a, b; Barua and Bhadra 1999). The available information fail to provide a comprehensive protocol and understanding of micropropagation of Spathoglottis plicata. The present investigation was, therefore, undertaken to develop a suitable protocol for in vitro fast regeneration system of this indigenous terrestrial orchid.

\section{Materials and Methods}

Mature pot plants of Spathoglottis plicata with deep pink coloured flowers were collected from a local nursery and used as source materials. About $2 \mathrm{~cm}$ long nodal segments, each with one node and an axillary bud (Fig. 1A) were used as explants.

Surface sterilized explants were cultured aseptically, initially in KC (Knudson 1946), VW (Vacin and Went 1949), MS and half strength of MS media. Each medium was initially supplemented with $3 \%$ sucrose, $2.0 \mathrm{mg} / 1 \mathrm{BA}, 0.5 \mathrm{mg} / \mathrm{l}$ NAA, $10 \% \mathrm{CW}$, and $2 \mathrm{~g} / \mathrm{l}$ peptone. The medium, which responded best, was used in subsequent experiments. The selected medium was supplemented with different concentrations and combinations of sucrose, auxins, cytokinins, peptone, coconut water, and activated charcoal to determine their optimum doses for getting highest number of PLBs/micro shoots. The cultures were gelled with $2.2 \mathrm{~g} / \mathrm{l}$ gelrite (Duchefa, The Netherlands). The $\mathrm{pH}$ of the medium was adjusted to 5.6 before autoclaving at a pressure of $1.06 \mathrm{~kg} / \mathrm{cm}^{2}$ and $121^{\circ} \mathrm{C}$ for 20 min. The medium was taken in $25 \times 150 \mathrm{~mm}$ culture tubes containing $12 \mathrm{ml}$ of medium. The cultures were kept at $24 \pm 1^{\circ} \mathrm{C}$ under fluorescence light intensity (2000 to 3000 lux) for $16 \mathrm{hr}$ photoperiod per day.

After hardening the plants were reared in the nursery up to flowering. Experiments were performed in a completely randomized design and all experiments were repeated three times. Each treatment had 15 replicates. The morphogenetic response of explants for PLB/micro-shoot induction was evaluated after 12 weeks of culture. For PLB/micro shoot proliferation and plantlet regeneration, results were evaluated after eight weeks of culture. Morphogenetic response was expressed as percentage of explants with PLB/ micro-shoot in relation to the number of surviving explants. For acclimation 50 
plantlets were taken for each treatment. Data were statistically analyzed and in some parameters means were compared using DMRT.

\section{Results and Discussion}

From the preliminary selection of defined nutrient medium, half strength of MS in combination with $2.0 \mathrm{mg} / \mathrm{l} \mathrm{BA}, 0.5 \mathrm{mg} / \mathrm{l}$ NAA, $3 \%$ sucrose, $10 \%$ coconut water and $2 \mathrm{~g} / \mathrm{l}$ peptone was found to be the most superior in all respects to other media and micro-shoots were directly induced from the explants without intervening PLBs. About $66.6 \%$ cultures of the nodal segment explants induced 6 micro-shoots per culture within 60.5 days (Data are not shown).

For further development of the medium, half strength of MS was used in combination with different plant growth regulators (PGRs) and organic supplements for high frequency induction of micro-shoots. Effects of BA, Kn and TDZ individually and in combinations with NAA and IAA in different concentrations on micro-shoot induction were determined (Table 1). BA (2.0 $\mathrm{mg} / \mathrm{l})+\mathrm{NAA}(0.5 \mathrm{mg} / \mathrm{l})$ was the most suitable combination for micro-shoot induction from cultured explants. Maximum number $(66.6 \%)$ of cultures produced micro-shoots in this particular medium composition. The highest number of micro-shoots per culture was 6 within 60 days of culture. So, for direct induction of micro-shoots from nodal explants the suitable PGRs combination as determined was $2.0 \mathrm{mg} / \mathrm{l} \mathrm{BA}+0.5 \mathrm{mg} / \mathrm{l} \mathrm{NAA}$ in half strength of MS with $3 \%$ sucrose $+10 \% \mathrm{CW}+2 \mathrm{~g} / \mathrm{l}$ peptone.

Teng et al. $(1997 a, b)$ obtained PLBs from nodal and leaf explants of eightmonth-old seedlings cultured on MS supplemented with 5.37 $\mu \mathrm{M}$ NAA and 0.44 $\mu \mathrm{M} B A$ and $2 \mathrm{~g} / \mathrm{l}$ charcoal and the best combination of PGRs for plantlet development was $2.69 \mu \mathrm{M}$ NAA + $8.88 \mu \mathrm{MBA}$. Earlier researchers used modified MS (Teng et al. 1997a, b; Barua and Bhadra 1999) for induction of PLBs from the explants. In the present experiments, half strength of MS was found to be suitable in relation to number of micro-shoots formed per culture. Half strength MS was also found suitable for in vitro regeneration of other orchids, like Epidendrum radicans (Chen et al. 2002b), Paphiopedilum (Chen et al. 2002a), and Phalaenopsis (Park et al. 2002, Sinha et al. 2006, 2007a,b).

For further improvement of the medium for obtaining large number of micro shoots, different concentrations of sucrose, $\mathrm{CW}$, peptone and activated charcoal were tried.

Sucrose (1 - 4\%) was used in half strength of MS with $10 \% \mathrm{CW}, 2 \mathrm{~g} / \mathrm{l}$ peptone, $2.0 \mathrm{mg} / \mathrm{l} \mathrm{BA}$ and $0.5 \mathrm{mg} / \mathrm{l} \mathrm{NAA} .2 \%$ sucrose in the medium induced highest number of micro-shoots from nodal segment explants, in which the number of micro-shoots induced from nodal segment was 12.2. 
Table 1. Effects of different concentrations and combinations of auxins and cytokinins on microshoot induction of Spathoglottis plicata.

\begin{tabular}{|c|c|c|c|}
\hline $\begin{array}{l}\text { PGRs } \\
(\mathrm{mg} / \mathrm{l})\end{array}$ & $\begin{array}{l}\% \text { of culture } \\
\text { induced micro-shoots }\end{array}$ & $\begin{array}{l}{ }^{*} \text { Days required for } \\
\text { micro-shoots induction }\end{array}$ & $\begin{array}{l}{ }^{*} \text { No. of micro- } \\
\text { shoots/explant }\end{array}$ \\
\hline \multicolumn{4}{|l|}{ BA } \\
\hline 1.5 & 12.5 & $64.6(4.7)$ & $1.5(0.4)$ \\
\hline 2.0 & 12.5 & $64.8(4.8)$ & $2.5(0.5)$ \\
\hline 2.5 & 20.8 & $63.1(4.6)$ & $2.5(0.5)$ \\
\hline \multicolumn{4}{|l|}{ Kn } \\
\hline 1.5 & 8.3 & $62.5(5.4)$ & $2.5(0.5)$ \\
\hline 2.0 & 12.5 & $62.8(5.5)$ & $3.0(0.0)$ \\
\hline 2.5 & 12.5 & $63.5(5.0)$ & $3.0(0.0)$ \\
\hline \multicolumn{4}{|l|}{ TDZ } \\
\hline 1.5 & 18.5 & 65.8 (5.9) & $1.4 \quad(0.3)$ \\
\hline 2.0 & 32.6 & $57.3(4.9)$ & $1.5 \quad(0.6)$ \\
\hline 2.5 & 21.6 & $67.4(5.4)$ & $2.1(0.3)$ \\
\hline \multicolumn{4}{|c|}{$\mathbf{B A}+\mathbf{N A A}$} \\
\hline $1.0+0.5$ & 31.2 & $64.1(4.7)$ & $4.5(0.8)$ \\
\hline $1.5+0.2$ & 42.3 & $68.3(5.0)$ & $4.5(0.5)$ \\
\hline $1.5+0.5$ & 50.0 & $60.0(5.5)$ & $5.0(0.5)$ \\
\hline $2.0+0.5$ & 66.6 & $60.5(4.0)$ & $6.0(0.5)$ \\
\hline \multicolumn{4}{|c|}{$\mathbf{B A}+\mathbf{I A A}$} \\
\hline $1.0+0.5$ & 12.5 & $70.1(4.7)$ & $2.5(0.2)$ \\
\hline $1.5+0.2$ & 24.0 & $65.3(4.0)$ & $2.0(0.5)$ \\
\hline $1.5+0.5$ & 24.5 & $65.0(5.0)$ & $3.0(0.5)$ \\
\hline $2.0+0.5$ & 31.2 & $65.5(4.5)$ & $3.5(0.5)$ \\
\hline \multicolumn{4}{|c|}{$\mathrm{Kn}$ + IAA } \\
\hline $1.0+0.5$ & 12.5 & $74.1(4.2)$ & $2.5(0.8)$ \\
\hline $1.5+0.2$ & 31.2 & $68.3(4.0)$ & $2.5(0.5)$ \\
\hline $1.5+0.5$ & 31.2 & $65.0(5.5)$ & $3.0(0.5)$ \\
\hline $2.0+0.5$ & 31.2 & $65.5(4.0)$ & $3.0(09)$ \\
\hline \multicolumn{4}{|c|}{ Kn + NAA } \\
\hline $1.0+0.5$ & 12.5 & 70.5 (4.6) & $4.8(0.8)$ \\
\hline $1.5+0.2$ & 31.2 & $65.2(4.7)$ & $4.7(0.5)$ \\
\hline $1.5+0.5$ & 31.2 & $65.3(5.9$ & $4.5(0.5)$ \\
\hline $2.0+0.5$ & 42.3 & 60.7 (5.7) & $4.8(0.5)$ \\
\hline \multicolumn{4}{|c|}{ TDZ + IAA } \\
\hline $1.0+0.5$ & 10.5 & $72.1(4.7)$ & $2.2(0.2)$ \\
\hline $1.5+0.2$ & 20.0 & $68.3(4.0)$ & $2.0(0.3)$ \\
\hline $1.5+0.5$ & 21.5 & $69.0(5.0)$ & $3.0(0.5)$ \\
\hline $2.0+0.5$ & 11.2 & $75.5(4.5)$ & $3.5(0.5)$ \\
\hline \multicolumn{4}{|c|}{ TDZ + NAA } \\
\hline $1.0+0.5$ & 12.2 & $74.1(5.2)$ & $2.5(0.8)$ \\
\hline $1.5+0.2$ & 31.2 & $68.3(4.7)$ & $2.5(0.5)$ \\
\hline $1.5+0.5$ & 31.2 & $65.0(5.5)$ & $3.0(0.5)$ \\
\hline $2.0+0.5$ & 21.2 & $75.5(4.0)$ & $3.0(09)$ \\
\hline
\end{tabular}

*Data were recorded after 12 weeks. Results are mean of 12 cultures.

Effects of different concentrations of $\mathrm{CW}$ was studied by culturing the explants on half strength of MS with $2 \%$ sucrose $+2.0 \mathrm{mg} / \mathrm{l} \mathrm{BA}+0.5 \mathrm{mg} / 1 \mathrm{NAA}+$ $2 \mathrm{~g} / \mathrm{l}$ peptone and CW $(0-25 \% \mathrm{v} / \mathrm{v})$. CW $(13 \%)$ was the optimal concentration for 
induction of highest number of micro-shoots from nodal segment. Effect of different concentrations of peptone was studied by culturing the explants on half strength of MS with $2 \%$ sucrose $+2.0 \mathrm{mg} / \mathrm{l} \mathrm{BA}+0.5 \mathrm{mg} / \mathrm{l} \mathrm{NAA}+15 \%(\mathrm{v} / \mathrm{v}) \mathrm{CW}$ and peptone $(0-3.0 \mathrm{~g} / \mathrm{l})$. It was observed that $2.0 \mathrm{~g} / 1$ peptone was the optimal concentration for induction of highest number (16.5) of micro-shoots. To determine the effects of activated charcoal (AC) on induction of micro-shoots from explants. AC $(0.5-2.0 \mathrm{~g} / \mathrm{l})$ was used in half strength of MS with $2 \%$ sucrose $+2.0 \mathrm{mg} / \mathrm{l} \mathrm{BA}+0.5 \mathrm{mg} / \mathrm{l} \mathrm{NAA}+2 \mathrm{~g} / \mathrm{l}$ peptone $+15 \%(\mathrm{v} / \mathrm{v}) \mathrm{CW})$. In the present study it was observed that $0.5 \mathrm{~g} / \mathrm{l} \mathrm{AC}$ was the optimal concentration for induction of highest number (19.5) of micro-shoots from nodal segment explants (Figs. 1B). So, the medium as determined for high frequency induction of microshoots directly from the explants was half strength of MS with $2 \%$ sucrose +2.0 $\mathrm{mg} / \mathrm{l} \mathrm{BA}+0.5 \mathrm{mg} / \mathrm{l} \mathrm{NAA}+2 \mathrm{~g} / \mathrm{l}$ peptone $+15 \%$ (v/v) CW + $0.5 \mathrm{~g} / \mathrm{l} \mathrm{AC}$.

Teng et al. (1997a,b) used 3\% sucrose in MS and obtained PLBs of Spathoglottis plicata. Bui et al. (1999) used 3\% sucrose for obtaining shoot buds directly from explants of Rhynchostylis gigantea. Addition of $10 \%$ coconut water to the culture medium also enhanced proliferation of protocorms and stimulated shoot development in Cymbidium (Nayak et al. 2006) and Phalaenopsis (Park et al. 2002). Peptone and tryptone were used in culture medium as organic sources of nitrogen (Arditti 1982). Evers (1984) showed the promotive effect of charcoal on the growth and organogenesis. In the present study, besides PGR, peptone, CW and activated charcoal were added to the culture medium simultaneously, which successfully enhanced the number of micro-shoot induction per culture. The cumulative effects of these three additives certainly acted on high frequency induction of micro-shoot

Through the eight-week subculture the number of micro-shoots increased up to an average number of 60 (Fig. 1C). The micro-shoot clumps were then dissected longitudinally containing an average of 15 micro-shoots in each section. They were subcultured on the same nutrient medium without PGR, where within eight weeks the micro-shoots were proliferated into a huge number but they were not developed into proper shoots. In another experiment the microshoot clumps were subcultured on the medium mentioned above along with different concentrations (50 - $250 \mathrm{mg} / \mathrm{l})$ of L-glutamine and casein hydrolysate $(\mathrm{CH})$ individually for eight weeks. Results showed that in eight week of subculture on medium having $200 \mathrm{mg} / \mathrm{l} \mathrm{L}$-glutamine the micro-shoots developed into shoots and elongated properly (Fig. 1D). The mean height of the shoots (including leaves) was $70.7 \mathrm{~mm}$ (Table 2). Moreover, a large number of secondary micro-shoots were induced from the base of the developing shoots. On the other hand, the lengths of the shoots developed from the micro-shoots cultured on the medium having $150 \mathrm{mg} / \mathrm{l} \mathrm{CH}$ was $53.6 \mathrm{~mm}$. So, the medium as 
determined, for shoots development and secondary micro-shoots induction was half strength of MS $+2 \%$ sucrose $+15 \% \mathrm{CW}+2 \mathrm{~g} / \mathrm{l}$ peptone $+0.5 \mathrm{~g} / \mathrm{l}$ activated charcoal + $200 \mathrm{mg} / \mathrm{l} \mathrm{L-glutamine}$.
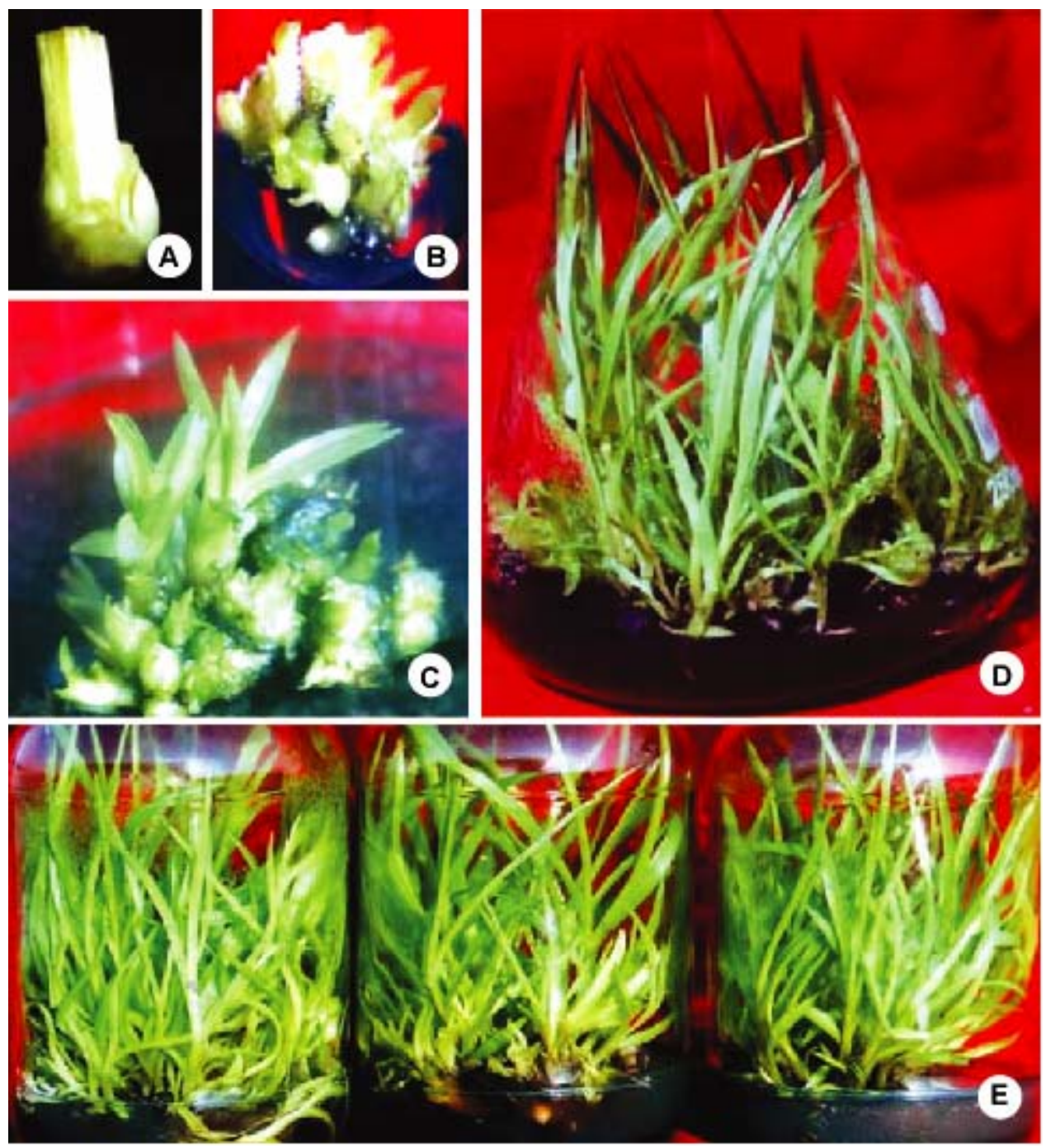

Figs. 1. (A). Nodal segment explant. (B). Micro-shoots induction from nodal segment. (C). Multiplication and elongation of regenerated micro-shoots at eight-week. (D). Development of micro-shoots into shoots and formation of secondary micro-shoots at eight-week. (E). Induction of roots.

The high frequency induction of secondary micro-shoots was possible probably due to the synergistic effect of the organic compounds present in $\mathrm{CW}$ and L-glutamine. Moreover, subculture of clumps of micro-shoots is much easier and efficient in comparison with subculture of individual PLB sections as 
determined in previous study (Teng et al. 1997 a,b). L-glutamine is most commonly used as organic nitrogen source (Pierik 1987).

Table 2. Effects of L-glutamine and casein hydrolysate $(\mathrm{CH})$ individually on shoot development from micro-shoots.

\begin{tabular}{|c|c|c|}
\hline \multirow{2}{*}{$\begin{array}{l}\text { L-glutamine/ CH } \\
(\mathrm{mg} / \mathrm{l})\end{array}$} & \multicolumn{2}{|c|}{ Nodal segment derived shoots } \\
\hline & ${ }^{\Psi}$ Shoot height $(\mathrm{mm})$ & Remarks \\
\hline \multicolumn{3}{|l|}{ L-glutamine } \\
\hline 0 & $20.5 \pm 2.4 \mathrm{~d}$ & * \\
\hline 50 & $40.7 \pm 2.5 \mathrm{c}$ & * \\
\hline 100 & $43.3 \pm 3.2 \mathrm{c}$ & * \\
\hline 150 & $59.9 \pm 3.4 b$ & * \\
\hline 200 & $70.7 \pm 4.6 \mathrm{a}$ & * \\
\hline 250 & $44.1 \pm 3.1 \mathrm{c}$ & * \\
\hline \multicolumn{3}{|l|}{$\mathrm{CH}$} \\
\hline 0 & $21.2 \pm 2.3 \mathrm{~d}$ & * \\
\hline 50 & $29.2 \pm 2.0 \mathrm{~d}$ & * \\
\hline 100 & $36.2 \pm 2.4 \mathrm{c}$ & * \\
\hline 150 & $53.6 \pm 3.3 \mathrm{~b}$ & * \\
\hline 200 & $41.5 \pm 3.4 \mathrm{c}$ & * \\
\hline 250 & $26.9 \pm 2.9 \mathrm{~d}$ & * \\
\hline
\end{tabular}

$\Psi$ Mean values \pm SE followed by the same letter in a column are not significant at $\mathrm{p}=0.05$ by DMRT. *Shoot development with shoot growth and formation of secondary micro shoots. Data were recorded in eight weeks of culture. Results are mean \pm SE of 15 cultures, repeated three times.

To obtain rooted plantlets the shoots were taken out from the culture vessels and subcultured on half strength of MS supplemented with $2 \%(\mathrm{w} / \mathrm{v})$ sucrose + $15 \%(\mathrm{v} / \mathrm{v}) \mathrm{CW}+2 \mathrm{~g} / \mathrm{l}$ peptone $+0.5 \mathrm{~g} / \mathrm{l} \mathrm{AC}$ along with banana pulp and potato homogenate (25 - $100 \mathrm{~g} / \mathrm{l})$ individually to observe their efficacy in root induction and growth. Adding of $50 \mathrm{~g} / \mathrm{l}$ banana pulp in the medium induced an average of 6 roots in 100\% cultures within eight weeks. The mean length of root was $68 \mathrm{~mm}$ (Table 3). Roots were also induced from the shoots cultured on medium containing potato homogenate within eight weeks but the frequency was not appreciable (Table 3). For rooting, Barua and Bhadra (1999) cultured regenerated shoots of Spathoglottis plicata on MS with $0.5 \mathrm{mg} / \mathrm{l}$ IAA, on which 3.2 roots were induced from each shoot. In the present study the addition of $50 \mathrm{~g} / \mathrm{l}$ banana pulp to the medium induced an average of six roots in $100 \%$ shoots within eight weeks, as it is especially promotive for growth in orchid culture (Pierik 1987).

After hardening the plantlets were implanted in plastic basket containing coconut husk $\left(10 \mathrm{~mm}^{2}\right)$. After 30 days the plantlets were implanted in clay pots (Fig. 2A ) containing alluvial soil and compost (3:1) and kept under shade net. The plants were watered every seven days and they were fertilized with a mixture of urea, triple super phosphate (TSP) and muriate of potash (MOP) 
$(2: 1: 1)$ at $25 \mathrm{~g} /$ plant at three months intervals. In three years the plants increased in height, and blossomed in two - four inflorescence stalks per plant cluster (Fig. 2C).
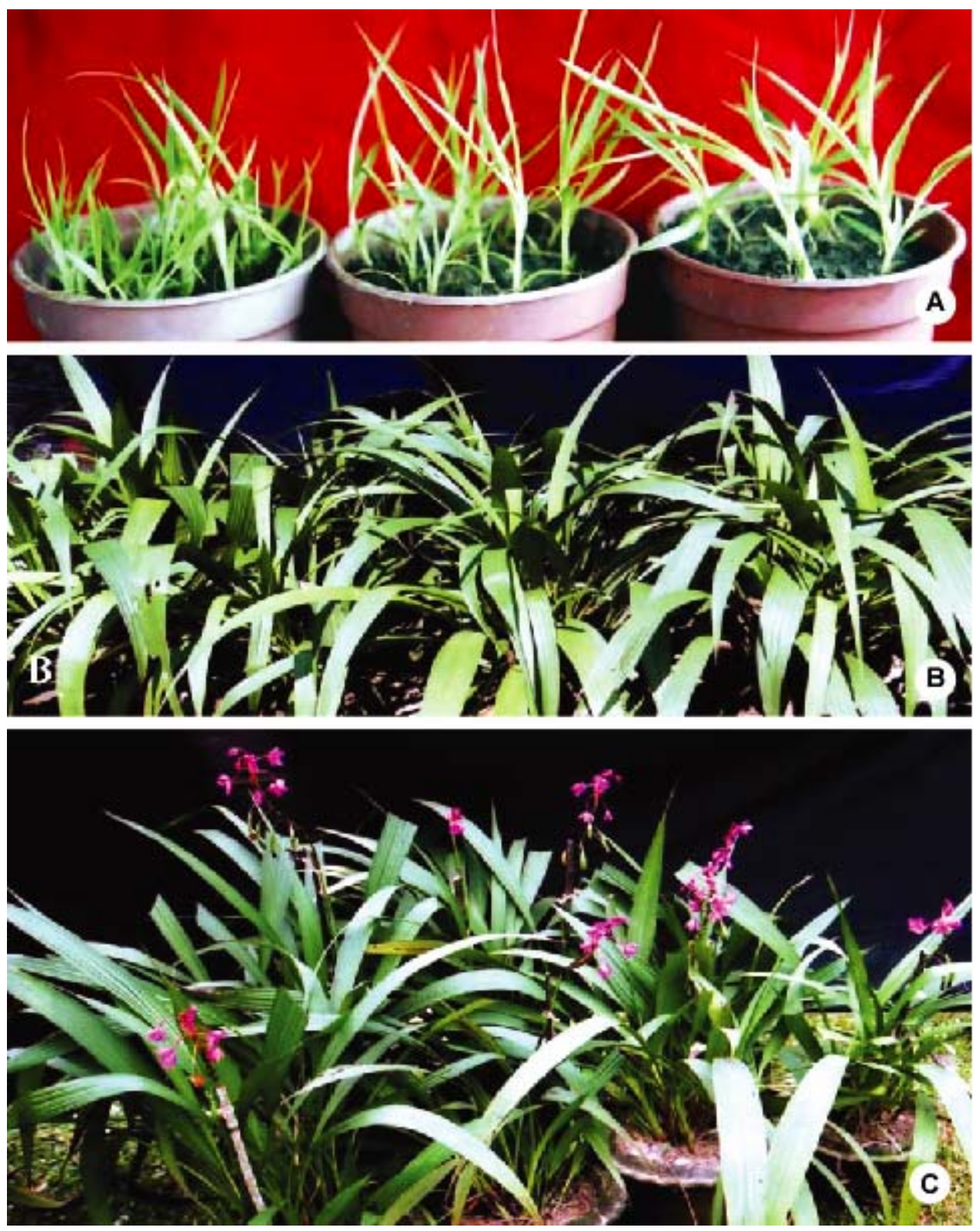

Fig. 2. (A). Acclimated plantlets in pots. (B). Two-year-old plants. (C). Three-year-old plants with flowers.

As in the present study plants were directly regenerated through microshoot formation from explants without the intervention of callus, and the growth regulators (BA and NAA) were used in small doses only in micro-shoot 
induction medium, there was no risk of somaclonal variation. In in vitro culture, the excessive use of growth regulators, and especially during the intermediary callus phase is undesirable as those are thought to be the main causes of variation in plants cultured in vitro (Prakash et al. 1996). In the present study it

Table 3. Effects of different concentrations of banana pulp (BP) and potato homogenate (PH) on root induction from shoots.

\begin{tabular}{cccc}
\hline BP/ PH & \multicolumn{3}{c}{ Nodal segment derived shoot } \\
\cline { 2 - 4 }$(\mathrm{g} / \mathrm{l})$ & $\begin{array}{c}\text { \% shoots } \\
\text { rooted }\end{array}$ & $\begin{array}{c}\text { *Mean number } \\
\text { of root } \pm \mathrm{SE}\end{array}$ & $\begin{array}{c}\text { Mean length }(\mathrm{mm}) \\
\text { of root } \pm \mathrm{SE}\end{array}$ \\
\hline BP & & & \\
25 & 53.42 & $3.2 \pm 0.7 \mathrm{c}$ & $40.5 \pm 4.2$ \\
50 & 100 & $6.3 \pm 0.7 \mathrm{a}$ & $70.5 \pm 4.3$ \\
75 & 81.43 & $4.3 \pm 0.4 \mathrm{~b}$ & $49.3 \pm 4.5$ \\
100 & 38.56 & $4.3 \pm 0.5 \mathrm{~b}$ & $36.4 \pm 3.1$ \\
& & & \\
PH & & $3.2 \pm 0.9 \mathrm{c}$ & $32.4 \pm 2.6$ \\
25 & 47.34 & $4.2 \pm 0.5 \mathrm{~b}$ & $45.7 \pm 5.5$ \\
50 & 61.91 & $3.0 \pm 0.5 \mathrm{c}$ & $35.1 \pm 3.4$ \\
75 & 51.49 & $3.41 \pm 0.3 \mathrm{c}$ & $35.9 \pm 2.8$ \\
100 & 30.43 & &
\end{tabular}

Fifteen cultures were taken for each treatment and the experiments were repeated three times. * Mean values followed by the same letter in a column are not significantly different at $\mathrm{p}=0.05$ by DMRT. Data were recorded in eight weeks after inoculation.

was avoided. The protocol as developed in the present study was through adjusting and determining the optimum concentrations and combinations of PGR, organic supplements and other medium adjuncts. The protocol is reproducible and would be utilized in high frequency regeneration of Spathoglottis plicata for commercial as well as conservation aspects.

\section{References}

Arditti J (1982) Orchid Biology: Reviews and perspectives, Vol. 2. Cornell Univ. Press, Ithaca, New York, p. 390.

Barua AK and Bhadra SK (1999) In vitro micropropagation of Cymbidium aloifolium (L.) Sw. and Spathoglottis plicata Bl. Plant Tiss. Cult. 9: 133-140.

Bui VL, Hang Phuong NT, Anh Hong LT and Van KTT (1999) High frequency shoot regeneration from Rhynchostylis gigantea (orchidaceae) using thin cell layer. Plant Growth Reg. 28: 179-185.

Chen TY, Chen JT and Chang WC (2002a) Multiple shoot formation and plant regeneration from stem nodal explants of Paphiopedilum orchids. In Vitro Cell. Dev. Biol.-Plant. 38: 595-597.

Chen LR, Chen JT and Chang WC (2002b) Efficient production of protocorm-like bodies and plant regeneration from flower stalk explants of the sympodial orchid Epidendrum radicans. In Vitro Cell. Dev. Biol.-Plant 38: 441-445. 
Evers N (1984) Growth and morphogenesis of shoot initials of Doglas fir, Pseudotsuga mensiesii (Mirb.) Franco, in vitro. Diss. Agric. Univ. Wageningen, the Netherlands, pp. 1-6.

Huda MK, Rahman MA and Wilcock CC (1999) A preliminary checklist of orchid taxa occurring in Bangladesh. Bangladesh J. Plant Taxon. 6: 69-85.

Knudson L (1946) A new nutrient solution for germination of orchid seed. Am. Orchid Soc. Bull. 15: 214-217.

Mukherjee SK (2002) Orchids. Indian Council of Agricultural Research, First published 1983, Reprinted 2002, New Delhi, India, p. 102.

Nayak NR, Tanaka M and Teixeira da Silva JA (2006) Biotechnology of Cymbidium- an overview of recent progress and future opportunities. In: Teixieira da Silva JA (Ed), Floriculture, Ornamental and Plant Biotechnology: Advances and Topical Issues, Vol. IV, Global Science Books, London, pp. 558-562.

Park SY, Murthy HN and Paek KY (2002) Rapid propagation of Phalaenopsis from floral stalk-derived leaves. In Vitro Cell. Dev. Biol.-Plant 38: 168-172.

Pierik RLM (1987) In vitro culture of higher plants. Martinus Nijhoff Publishers, Dordrecht, Boston, Lancaster. p. 344.

Prakash L, Lee C L, Loh CS and Goh C J (1996) In vitro propagation of commercial orchids: an assessment of current methodologies and development of a novel approach - thin cross-section culture. In: Islam AS (Ed), Plant Tissue Culture. Oxford \& IBS Publishing Co. Pvt Ltd, New Delhi, Calcutta, pp. 42-49.

Roy S and Biswas AK (2004) In vitro regeneration and hardening of plantlets through seed culture in Spathoglottis plicata Blume. In: Islam AS (Ed), In Vitro Culture, Transformation and Molecular Markers for Crop Improvement. Oxford \& IBH Publishing Co. Pvt. Ltd., New Delhi (India) and Science Publishers, Inc., Enfield (USA), Plymouth (UK), pp. 11-16.

Sarker RH and Roy AR (1993) In vitro propagation of local orchids from Bangladesh. In Vitro Cell. Dev. Biol. 29A (Part II): 90A.

Sinha P, Hakim ML and Alam MF (2006) Continuous high-frequency regeneration of different Phalaenopsis cultivars from young leaves of mature plants. In: Teixeira da Silva J.A. (ed) Floriculture, Ornamental and Plant Biotechnology Advances and Topical Issues, Vol. 4, Global Science Book, UK, pp. 594-598.

Sinha P, Hakim ML and Alam MF (2007a) Clonal propagation of white flowered hybrid Cattleya through in vitro culture of thin cell layers from young shoots of mature plants. Orchid Sci. Biotech. 1: 24-28.

Sinha P, Hakim ML and Alam MF (2007b) Efficient micropropagation of Phalaenopsis amabilis (L.) Bl. cv. 'Cool Breeze' using inflorescence axis thin sections as explants. Propagation of Ornamental Plants 7: 9-15.

Teng WL, Nicolson L and Yu LYY (1997a) Clonal propagation of Spathoglottis plicata from young plants. Acta Hort. 447: 115-119.

Teng WL, Nicholson L and Teng MC (1997b) Micropropagation of Spathoglottis plicata. Plant Cell Reports 16: 831-835.

Vacin E and Went F (1949) Some pH changes in nutrient solutions. Bot. Gaz. 110: 605-613. 